\title{
Development of Pamekasan Batik Motifs as the Application of Product Diversifications
}

\author{
Fera Ratyaningrum ${ }^{1, *}$ Trisakti $^{1}$ Indah C. Angge ${ }^{2}$ Marsudi $^{3}$ \\ 1,2,3 Universitas Negeri Surabaya, Indonesia \\ *Corresponding author. Email: feraratyaningrum@unesa.ac.id
}

\begin{abstract}
Pamekasan Regency has batik products as the center of batik industrialization in Madura. More specifically, Klampar village. Pamekasan Regency has a batik industry center, one of which is Klampar village, Proppo sub-district. The handcrafted batik of Klampar Village has a positive impact on the socio-economic conditions of the community. Pamekasan batik motifs generally explore specific forms of flora and fauna, namely butterflies, birds, and chickens. There are three levels of social structure or hierarchy in the batik industry, namely the upper layer (buyers, collectors/prominent entrepreneurs), the middle layer (small home industry entrepreneurs), and the lower layer (batik workers). Pamekasan batik craftsmen have high capture and creativity in making motifs on a piece of batik cloth. So far, the creativity is still limited to long cloth products and clothing materials. Based on this background, the purpose of this research is to develop Pamekasan batik motifs to apply them to interior products as one of the innovations in diversifying the batik product itself as Indonesian cultural heritage in particular.
\end{abstract}

Keywords: Pamekasan batik, Batik motif, Product diversification.

\section{INTRODUCTION}

The biggest batik center in East Java is in Pamekasan Regency which is in Madura Island. One of the biggest batik industrializations in Pamekasan Regency is in Klampar Village. There are no less than 600 homemade batik artisans, including about 80 batik entrepreneurs who employ an average of 12 people. Every week more than 5,000 pieces of Madura batik cloth spread to Surabaya and other cities [1]. The handcrafted batik of Klampar Village has a positive impact on the socioeconomics of the Klampar Village community, including the opening of jobs as batik craftsmen, especially for housewives who can fill their spare time with batik to improve the community's economy. Pamekasan batik has a bolder characteristic using sharp colors. The motifs are abstract, mountain, and vintage or old [2].

The unbalanced relationship between crafters and factory workers with big buyers/entrepreneurs weakens the creative power of crafters. This gives rise to domination-subordination relations between social actors, thus creating power and social inequality [3]. This is one of the causes of the monotonous design of Pamekasan batik. The design of the created batik motif has the same impression because it emphasizes the low price. Therefore, it is necessary to develop motifs that can be applied to various interior products as diversification of batik motifs to expand and enrich product diversity.

Diversification is the act of making things more diverse to not be fixated on one thing. In, this is associated with production operations that are not dependent on selling one type of product to increase profitability and reduce risk [4]. Various reasons encourage a company to diversify its products, and the main one is the desire to expand its business. The possibility of getting a profit will also be greater because it produces several goods needed by consumers due to the loss of selling one item can be covered by the profit of selling other goods. Product diversification aims to meet consumer tastes, needs, and expectations in expanding markets and providing added value. To diversify products requires creativity, innovation, research, capital, promotion or marketing communications, assistance from the government for small and medium enterprises [5]. This product diversification will be applied to Pamekasan batik motifs which have been produced in the form of long cloth (jarit), sarongs, and clothing materials. Interior products become a medium for the development of Pamekasan batik motifs. 
The placement of batik motif elements to preserve the motif can be done by applying this redesigned batik motif to the interior design elements such as the floors and walls in the lobby area, business center area, and bedrooms as well as the furniture design to maintain the cultural elements of an area with some adjustments in the design of shapes and colors [6]. Based on the background of the problem described above, the purpose of this research is to develop Pamekasan batik motifs for interior products as an effort to diversify Pamekasan batik products.

\section{METHODS}

Research and development method was used to produce certain products (batik) and test the effectiveness of these batik products [7]. This time the development of the 4-D method is used to develop Pamekasan motifs into interior products. The development model that is used as a reference in this study is the Thiagarajan model, namely: Define, Design, Develop and Disseminate [8].

In more detail, the research development process using the 4D model is described as follows: (1) The Defining Phase begins with identifying research problems, namely in the development of Pamekasan batik starting to find a point of saturation with the emergence of price wars because batik artisans cannot develop designs. Next is the data collection stage through a preliminary study/preliminary study of the conditions and situations in the Pamekasan batik center to determine the needs analysis of the crafters to be used as interior products, namely the existence of innovations for the development of motifs; (2) The Design Phase produces Pamekasan batik motifs for interior products. Starting from extracting ideas from Pamekasan batik motifs that are still original, then sketches and motif outlines are drawn on a 1:1 scale to be traced on the fabric; (3) The Development Phase (Develop) produces interior products that apply Pamekasan batik motifs. Starting with sketching the motif, the process of batik, and the installation process in interior products. Interior products in the form of office chairs, sofa, table-cover, and pillowcases; (4) The dissemination stage introduces interior products that apply Pamekasan batik motifs by holding product exhibitions.

The study obtained data that are primary and secondary. The first primary data came from in-depth interviews used to obtain information from batik artisans in the Pamekasan batik center. The data was about the Pemekasan batik motifs and the real obstacles faced by batik makers. The second was the observation, which was used to observe the process of batik at the Pamekasan batik center and the obstacles faced during the batik process. The data documentation came from references of Pamekasan batik motifs in the form of cloth products as well as pictures from documentation and batik literature books containing Pamekasan batik motifs. The secondary data was from literature studies carried out by researchers by collecting, reading and observing, studying and analyzing, as well as reviewing secondary data and data sources in the form of books and websites.

\section{RESULTS AND DISCUSSION}

Besides maintaining its tradition, Batik Pamekasan also adds motifs by following current trends such as bird, floral, cheating, and contemporary [9]. Pamekasan batik motifs generally explore specific flora and fauna such as butterflies, birds, and chickens. Typical Pamekasan Isens include spilled rice, cecek pitu, cecek telu [10]. The development of batik motifs in the village of Klampar Pamekasan has undergone changes caused by environmental, social factors that have changed, the economy is growing, and in preserving culture [2]. The market demand changes and developments require craftsmen to create new motifs. Creativity and visual exploration are needed by craftsmen in making creative motif designs. Most batik artisans in Pamekasan rely on the inheritance of family-based batik traditions and are fixated on existing visual habits and patterns [11].

\subsection{Define Stage}

The development of Pamekasan batik motifs for interior products as preservation of cultural heritage refers to the butterfly, one of the faunas commonly found in Pamekasan. This butterfly was chosen based on the meaning of the butterfly philosophy in batik. Butterfly means enlightenment or the pinnacle of perfection. The meaning is based on the description of the perfect metamorphosis process from a caterpillar, a cocoon, to a butterfly. It takes several stages for something terrible to become something good. This illustrates the message that humans must try earnestly, restrain themselves, and be patient, to get good results [12]; [13]. Figure 1 below is an example of the application of the butterfly motif on Madura batik.
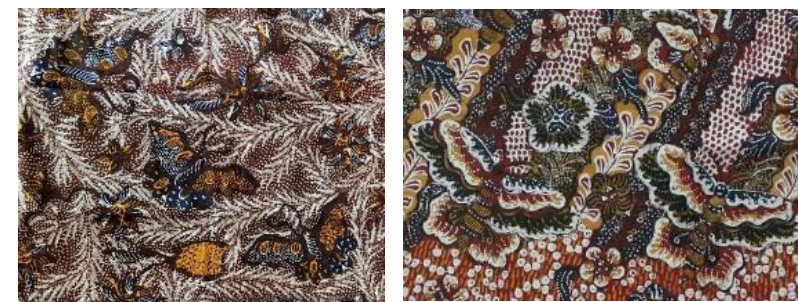

Figure 1 Butterfly motifs are applied into Pamekasan batik (source: Ratyaningrum, 2021)

\subsection{Design Stage}

The determination of the butterfly as the main motif in the development of Pamekasan batik designs becomes the initial step to proceed to the next stage that is the design phase. This design phase begins with an initial sketch in pencil and on paper to explore different design 
alternatives. In addition to designing butterfly motifs, this stage also explores isen motifs that are floral.

Most batik motifs are made from stylization from flowers and leaves [14], so Madurese batik motifs use a lot of floral and leaf motifs [15]. The butterfly batik motif is depicted with a slight stylization in its shape. The depiction of similar shapes and compositions is intended so that the motif can still be identified from the origin of the idea because batik has various batik styles. The symmetrical placement of the wings and the depiction of the shape of the flowers in roses convey a message that we as humans should be able to see things from a comprehensive perspective and maintain balance inside and out. For example, in this pandemic era, we must not only look at the negative side but also take positive values and lessons. Figure 2 below is the implementation of motif designs.

The sketch that has been filled with markers is then scanned for tracing in digital form. This digital motif design facilitates the process of setting the design composition and coloring process. The colors applied still refer to the characteristics of Madurese batik which are bright and bold colors, such as red, yellow, and green [15].

This research resulted in seven sets of design developments in seat cushion covers, backrest covers, and tablecloths based on the Madura butterfly motif. Each product produces a varied composition of motifs and color compositions. The following of Figure 2 are the results of the development of the motifs applied to the seat back interior products.
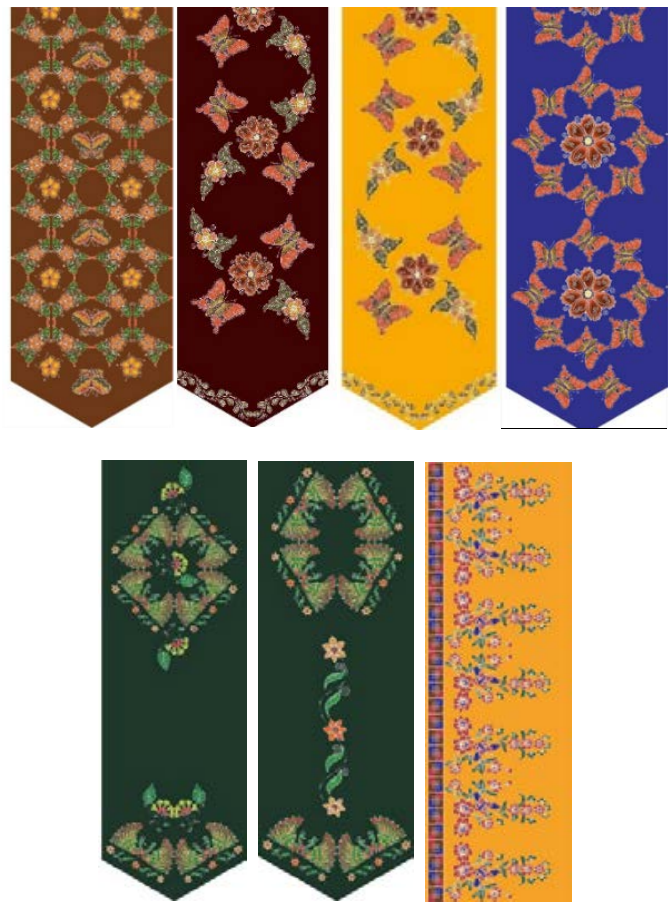

Figure 2 Implementation of motif designs form left to right, contain: design (1), (2), (3), (4), (5), (6) and (7) (source: Ratyaningrum, 2021)

\subsection{Develop Stage}

The seven sets of motif designs were validated by peer reviewers who understand the application of batik design motifs, especially Madura batik. The validation results based on a Likert scale from 1-4 showed that designs number 2, 4 and 6 touch the perfect number of indicators. These indicators are: (1) Innovation consists of shape, composition and color (2) Conformity with the original motif, consisting of: shape, composition and color (3) Form proportionality (4) Color composition (5) Harmony of form and color (6) Do not leave the original motif.

Based on the seven designs, the lowest points are on the color composition and the harmony of shapes and colors from these indicators. In terms of innovation, all designs have innovations in terms of shape, composition and color. All designs also do not leave the original form of Madurese batik.

\subsection{Disseminate Stage}

Furniture is one of the categories of design elements that must always be present in almost all interior designs. Furniture is an intermediary between architecture and people. Accessories that can add visual richness and taste to an interior arrangement. They can be in the form of valuable objects or decorative elements [16]. Furniture as an interior component also fulfils human needs for furniture functionally and has a decorative value that is dominant for a room inhabited by humans. So it can be said that this furniture also has a high artistic value [17]. Batik derivative products can be in the form of household accessories, curtains, and wall paintings [17]. Batik is flexible to be applied to office interior design, both contemporary and traditional. The application of batik to furniture, the choices of batik motifs used, and their placement, should also be considered [18].

As a complement to the house's interior, batik motifs can be applied in the living room on chair cushions, tablecloths, wall hangings, and decorative lights. In the bedroom, batik motifs can be used to bedding such as sheets and bolster pillowcases along with blankets (bedcovers), and headboard covers [19].

The office chair as an interior product was chosen because it means of the philosophy of the butterfly motif which is a change. By placing it in an office chair, it is hoped that the owner/user of the chair can be inspired and can continue to experience making changes for the better like a butterfly. Figure 3 below applies the butterfly motif design on work chairs and the office's living room desk chairs. 


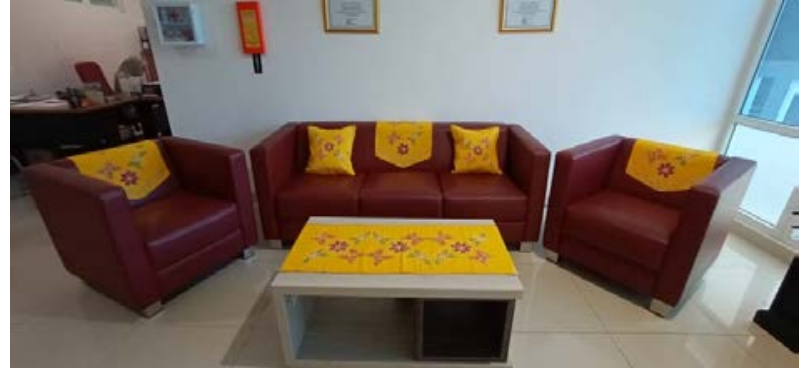

Figure 3 Motif designs are applied to the sofa and table. (source: Ratyaningrum, 2021)

The development of the application of batik motifs is an idea in design with various media. Through proper placement, batik motifs can enhance a certain image from the visual form of design, giving a special characteristic that raises local thematic content in today's designs. The application of batik can provide knowledge about the preservation of batik so that it still exists in the life of today's society. In creating batik on cloth on furniture/sofa, the manufacturing process is the same as the process of making written batik, starting from making motif designs, making batik using canting, up to the same color as the batik above on the cloth [20].

\section{CONCLUSION}

The development of Pamekasan batik motifs for interior products as preservation of cultural heritage produces butterfly and flower motifs both as the main and floral motifs as well as filler motifs (isen). It begins with the determination of butterflies as the main motif and flowers as filler motifs (isen). Design exploration with pencil sketches on paper led to two butterfly designs and one floral design. Both of these designs were digitized with a drawing software program. The final design is applied to the seat, also through a digital process. So that we get a chair design by applying a butterfly design motif.

The development of Pamekasan batik motifs for interior products begins with the selection of objects in the form of butterflies and flowers. Next, a design sketch is made on paper by placing butterfly and flower motifs as the main motif or additional motifs. The results of the design sketch are then digitized with a drawing program software, making it easier to explore colors and compositions. After selecting the color, the design is ready to be applied to the fabric and made into batik with the final product in the form of work chair covers, sofa covers and chair cushion covers, and office living room table covers.

\section{ACKNOWLEDGMENTS}

This research was supported granted by the Faculty of Language and Art of Universitas Negeri Surabaya and fully supported by LPPM (Institution of Research and
Community Service) Universitas Negeri Surabaya (UNESA).

\section{REFERENCES}

[1] N.A. Aziz, “'Ngejreng' yang Memikat dari Madura,” kompas.com, 2010. Available: https://money.kompas.com/read/2010/06/03/14335 857/ Tanah Air. [Accessed Mar. 24, 2021].

[2] M.E. Prasetyaningrum, "Perkembangan Batik Tulis Di Desa Klampar Kabupaten Pamekasan Tahun 2009-2017,” Avatara, vol. 8, no. 1, pp. 1-9, 2020, [Online].

Available: https://jurnalmahasiswa.unesa.ac.id/index.php/avat ara/article/view/32036.

[3] O.R. Sutopo, "Faktor struktural dan kultural penyebab kesenjanngan sosial: kasus industri batik Pamekasan Madura,” J. komunitas, vol. 5, no. 2, pp. 230-239, 2013.2 DOI: 10.15294/komunitas.v5i2.2741.

[4] T. Thidi, "Cara Meningkatkan Profitabilitas dan Mengurangi Resiko Dengan Diversifikasi,” thidiweb.com, 2020. [Online]. Available: https://thidiweb.com/pengertian-diversifikasi/.

[Accessed Mar. 28, 2021].

[5] L. Hermawan, "Dilema diversifikasi produk: meningkatkan pendapatan atau menimbulkan kanibalisme produk?,” Stud. Manaj., vol. 9, no. 2, pp. 142-153, 2015.2 DOI: https://doi.org/10.21107/kompetensi.v9i2.

[6] A.S. Azka, S.I. Adisurya, and H. Bisnis, "Penerapan Motif Batik Yogyakarta pada Desain Interior,” in Proc. Seminar Nasional Cendekiawan ke-5, 2019, pp. 1-6.

[7] S. Sugiyono, Manajemen Pendidikan Kejuruan. Yogyakarta: Fakultas Teknik UNY, 2016.

[8] S. Thiagarajan, Instructional development for training teachers of exceptional children: A Sourcebook. Bloomington, Indiana: Indiana University, 1974.

[9] R. Rusnani and I.Y. Andini, "Strategi pemasaran batik Madura dalam menghadapi pemasaran global,” PERFORMANCE, vol. IV, no. 2, pp. 1425, 2014. [Online]. Available: https://www.neliti.com/publications/292716/strateg i-pemasaran-batik-madura-dalam-menghadapipemasaran-global.

[10] K. Sastrodiwirjo, Heritage of Indonesia: Pamekasan Membatik. 2nd ed. PT. JEPE PRESS MEDIA UTAMA, 2012. 
[11] S. Wicaksana and A.S.E. Ahmad, "Kiprah Wahyu Subiyantoro dalam Pengembangan Teknik Pembuatan Motif Batik Pamekasan,” J. Seni Rupa, vol. 9, no. 1, pp. 130-145, 2021. [Online]. Available:

https://jurnalmahasiswa.unesa.ac.id/index.php/va/a rticle/view/36322.

[12] Infobatik-web-admin, "Batik Indonesia Motif Kupu-Kupu,” infobatik.com, 2019. [Online]. Available: $\quad$ https://www.infobatik.com/batikindonesia-motif-kupu-kupu/

[13] N.S. Ningrum, "Kenali ilosofi di balik ornamen batik sidomukti," semarangpos.id, 2020. [Online]. Available: https://www.semarangpos.com/kenalifilosofi-di-balik-ornamen-batik-sidomukti1045037. [Accessed Jul. 18, 2021].

[14] F. Ratyaningrum and E.A. Oemar, "Values of Local Wisdom in Dlongop Batik Motif," Advances in Social Science, Education and Humanities Research (ASSEHR), vol. 108, pp. 213-217, 2018. DOI: https://doi.org/10.2991/soshec-17.2018.42

[15] R.A.S. Suminto, "Batik Madura : menilik ciri khas dan makna filosofinya," CORAK, vol. 4, no. 1, pp. 1-12, 2015.2 DOI: https://doi.org/10.24821/corak.v4i1.2356

[16] M. Riadi, "Desain Interior (Elemen, Komponen, Aspek, Prinsip dan Model)," www.kajianpustaka.com, 2020. [Online]. Available: https://www.kajianpustaka.com/2020/07/desaininterior.html. [Accessed Mar. 28, 2021].

[17] P. Poerwanto and Z.L. Sukirno, "Inovasi Produk dan Motif Seni Batik Pesisiran sebagai Basis Pengembangan Industri Kreatif Dan Kampung Wisata Minat Khusus," AL-AZHAR Indonesia SERI PRANATA Sos., vol. 1, no. 4, pp. 217-229, 2012. Available: https://jurnal.uai.ac.id/index.php/SPS/article/view/ 71

[18] T. Atmadi, "Kajian Aplikasi Batik Pada Desain Interior Kantor Google di Jakarta," NARADA, vol. 2, no. 1, pp. 15-20, 2015.

[19] Fitinline, "Fungsi dan bentuk dasar motif batik serta pengaplikasinnya di berbagai meteria," fitinline.com, 2019. [Online]. Available: https://fitinline.com/article/read/fungsi-dan-bentukdasar-motif-batik-serta-pengaplikasiannya-diberbagai-material/. [Accessed Mar. 28, 2021].

[20] S.M. Sari, L.K. Wardani, and R.H.I. Sitindjak, "Implementasi Motif batik pada Desain Interior Modern dan Peran Pendidikan Seni dan Desain," in Proc. Seminar Nasional Pendidikan Seni, UNNES.
Indonesia, 2015, pp. 239-249. Available: http://repository.petra.ac.id/id/eprint/17210 